\title{
EXPLORING ARAB MIDDLE EASTERN WOMEN'S PERCEPTIONS OF BARRIERS TO, AND FACILITATORS OF, INTERNATIONAL MANAGEMENT OPPORTUNITIES
}

\author{
Kate Hutchings * \\ Department of Management \\ Monash University \\ Building 11E \\ Clayton Vic 3800 \\ AUSTRALIA \\ E-mail: kate.hutchings@buseco.monash.edu.au \\ Beverly Dawn Metcalfe \\ Business and Management Deanery \\ Liverpool Hope University \\ Hope Park Campus L16 9JD \\ UK \\ E-mail: metcalfebd@yahoo.co.uk \\ Brian K Cooper \\ Department of Management \\ Monash University \\ Building N \\ Caulfield Vic 3145 \\ AUSTRALIA \\ E-mail: kate.hutchings@buseco.monash.edu.au
}

Kate Hutchings (Ph.D, University of Queensland) is an Associate Professor in the Department of Management, Monash University, Australia. She has taught in China and Malaysia as well as having held visiting research positions in the US, Denmark, and France. Amongst others, her research has appeared in Human Resource Management Journal, International Journal of Human Resource Management, Journal of Management Studies, Journal of Organisational Change Management, and Thunderbird International Business Review. Her current research interests include expatriate management, HRM in China, Chinese outward foreign direct investment, and intercultural knowledge sharing.

Beverly Dawn Metcalfe (PhD, Keele University) is a Professor in International Management and Development at Liverpool Hope University, UK, and a Research Fellow in the Centre for Equality and Diversity, Manchester Business School, UK. Her research interests are in international human resource development and gender work and organisation in the global economy. She has done consultancy work for Bahrain and Iranian governments. Her research has been published inter alia in Journal of Business Ethics, International Journal of Human Resource Management, and Human Resource Development International.

Brian Cooper (PhD, La Trobe University) is Research Fellow in the Department of Management, Monash University, Australia. Brian is also a Lecturer in management research methods. He has extensive experience publishing survey and qualitative research. His research interests include stress and coping, employee wellbeing, and multivariate modelling.

* Please direct all correspondence to the first author 


\title{
EXPLORING ARAB MIDDLE EASTERN WOMEN'S PERCEPTIONS OF BARRIERS TO, AND FACILITATORS OF, INTERNATIONAL MANAGEMENT OPPORTUNITIES
}

\begin{abstract}
Extant research has suggested that there are four key barriers to women undertaking international assignments including corporate resistance, foreigner prejudice, women's own disinterest, and lack of family and other support mechanisms. While there has been substantive research investigating the existence of barriers to women undertaking international assignments, the vast majority of research has focused on Western women and Western multinational corporations (MNCs). This study sought to examine the disposition which Arab Middle Eastern women have towards undertaking international assignments. This research is significant because of the growing international strategic political and economic importance of many Arab Middle Eastern nations and that many Arab Middle Eastern women are highly educated and would prove a valuable human resource for international organisations. This paper reports the findings of a survey of 97 middle- and senior-level female managers in Bahrain, Egypt, Jordan, Saudi Arabia, Oman, Qatar, and the UAE, seeking to elucidate the factors which Arab Middle Eastern view as barriers to, or facilitators of, international management opportunities. The study is significant in a) extending research on women and international work to an Arab Middle Eastern context, b) expands understanding of what is international work by highlighting that the majority of Arab Middle Eastern women's managerial, international employment, and skills development opportunities come via non-government organisations and women's organisations. This makes their opportunities for international engagement very different from those of Western women who overwhelmingly receive international experience via MNCs, and c) extends understanding of international work barriers to include an assessment of national cultural and institutional issues.
\end{abstract}

Keywords Arab Middle East, international work, women, barriers, culture

\section{INTRODUCTION}

International businesses that employ international managers grapple daily with the need to address a complex array of issues around staffing, training, performance management and cross-cultural competencies associated with the increased demand for internationally proficient employees. Yet a major issue that remains unaddressed by many organisations but which has been erstwhile long-recognised in the international management literature is the under representation of women amongst international managers. Though women in Western nations (and to a lesser extent in developing nations in Eastern Europe, Asia, South America, 
Africa and the Middle East) are increasingly represented in senior management positions, particularly in the public sector and government roles, they remain an under-utilised resource in international work, despite research suggesting that they may, in some cases, actually be better positioned than men to handle international assignments (Altman \& Shortland, 2001). Recent research suggests that women account for only 14 per cent of expatriate executives posted from the USA and less than 5 per cent of those sent abroad from European companies (Van der Boon, 2003). Women from developing countries in Eastern Europe, Asia, South America, Africa and the Middle East are even less represented amongst international managers, despite their increasing representation at middle- and senior-level positions in their own countries. Significantly, international business research has only in the last two decades considered gendered dynamics as important as a category of analysis. Landmark research undertaken by Adler (1984a, 1984b, 1984c, 1994a, 1994b) explored three primary barriers to women's under-representation including; company resistance, foreigner prejudice, and women's own lack of interest in undertaking international assignments. Her research has been expanded upon since by authors such as Harris (2001, 2004), Harris \& Brewster (1999), Linehan (2000) and Linehan, Scullion \& Walsh (2001) who have added differing dimensions, including analysis of a fourth barrier, namely, lack of family and other support mechanisms, to our understanding of women in international management, but much of it has confirmed aspects of Adler's research suggesting that there are still obstacles to women's engagement in the international workforce.

This paper reports findings from an exploratory study which was designed to examine identified barriers to women taking international assignments are of relevance to women in the Arab Middle East, a region growing in international strategic political and economic importance and in which many women are highly educated and potentially a valuable human resource commodity for international businesses. While some of the perceptions of barriers initially discussed by Adler have been discredited in more recent research, studies have 
overwhelmingly focused on women from Western, industrialised nations. The study is significant for three reasons, namely, that it: a) extends research on women and international work to an Arab Middle Eastern context, b) expands understanding of what constitutes international work by highlighting that the majority of Arab Middle Eastern women's managerial, international employment, and skills development opportunities come via nongovernment organisations and women's organisations - which makes their opportunities for international engagement very different from those of Western women who overwhelmingly receive international experience via $\mathrm{MNCs}$, and c) extends understanding of international work barriers to include an assessment of national cultural and institutional issues.

Our research makes an important contribution to theoretical understanding of gender and theorising about differences for women in international management generally, and Arab, Islamic women, in particular. The study highlights gender as a category of analysis in international business research through advancing current knowledge of women's perceptions of barriers to, and facilitators of, international management opportunities.

This study complements earlier research but provides an additional dimension in considering women's own perceptions about cultural barriers to their participating in international work. The research is significant in that it explores women working in the Middle East Islamic states, a previously little represented group in management research. Our research also adds to the discourse on gendered international work opportunities in exploring whether the cited barriers (including lack of interest which has been exploded as a myth in the Western context) are of relevance for Arab Middle Eastern women, a cohort which is insufficiently explored in the international management literature (see Metcalfe, 2007). Moreover, while the extant research has explored elements of national culture in assessing whether foreigner prejudice limits women's international management opportunities (for a discussion of the relationship between sex and culture, see Cordano, Scherer, \& Owen, 2002), there has been limited discussion of whether the culture of the nation in which a woman 
currently abides and the culture and society with which she is identified impacts on her international work opportunities.

The research explores responses to a semi-structured survey provided by 97 middleand senior-level female managers from Bahrain, Egypt, Jordan, Saudi Arabia, Oman, Qatar, and the UAE. The research is significant for three reasons, namely, that it: a) extends research on women and international work to an Arab Middle Eastern context, b) expands understanding of what constitutes international work by highlighting that the majority of Arab Middle Eastern women's managerial, international employment, and skills development opportunities come via non-government organisations and women's organisations - which makes their opportunities for international engagement very different from those of Western women who overwhelmingly receive international experience via MNCs, and c) extends understanding of international work barriers to include an assessment of national cultural and institutional issues.

The key research questions addressed in this paper are:

- RQ1: What do Arab Middle Eastern women perceive as the barriers to women in the Arab Middle East taking international assignments?

- RQ1a: What are the perceived organisational and cultural barriers to international assignments?

- $\quad$ RQ1b: Is there perceived foreigner prejudice about Arab Middle Eastern women's abilities to culturally adjust internationally?

- $\quad$ RQ1c: Is there perceived corporate resistance to sending Arab Middle Eastern women on international assignments?

- $\quad$ RQ1d: Do Arab Middle Eastern women have a positive orientation towards taking international assignments? 
- $\quad$ RQ1e: Have Arab Middle Eastern women had experiences of being treated unfairly in various areas of HRM?

- RQ2: What factors do Arab Middle Eastern perceive as facilitators of opportunities for Arab Middle Eastern women to take international assignments?

- $\quad$ RQ2a: What training, education and developmental supports facilitate work opportunities?

- $\quad$ RQ2b: Are there areas in which Arab Middle Eastern women believe they have been provided with impediments to, or assistance, with international work opportunities?

The paper begins with a review of the literature on the role of international managers, women in international management and Middle Eastern women in international management. This is followed by a description of the survey. The results are then presented. A discussion is then provided which identifies how the findings of the research link to extant research. Finally, a conclusion section summarises the major contributions of the research, implications for theory and practice and issues for future research.

\section{GENDER AND HRM AND INTERNATIONAL MANAGEMENT IN REVIEW}

\section{Women in international management}

There is limited research of the gendered affects and gendered organizational processes of HRM in the international realm (Hearn et al., 2005; Nishii \& Oxbilgin, 2007 are exceptions). Women's role in international management, however, is an established field of study. Research conducted by Adler (1984a, 1984b, 1984c, 1987, 1994a, 1994b) has provided the most comprehensive examination of the role of women in international management. Adler and her successors (Harris, 1995; Heneman, Judge \& Heneman, 1999; Selmer \& Leung, 2002, 2003; Sinangil \& Ones, 2001; Sinangil \& Ones, 2003) have attributed the scarcity of female expatriates to three principle / principal causes: foreigners' prejudice, corporate resistance, 
and female managers' disinterest (the latter is now largely disputed) . Recent research has also suggested a fourth barrier (although it is not actually defined by the authors as such), namely, that a dearth of social network support (and we suggest this includes family support) available to female expatriates, and work-family conflict, is also a significant barrier to women's international work opportunities (Linehan, 2000; Linehan, et al., 2001).

\section{Foreigner prejudice}

A frequently mentioned reason for companies' hesitation to send female managers on international assignment is that foreigners' prejudice against women makes them ineffective as managers. Almost three-quarters of human resource managers from MNCs surveyed believed that foreigners are so prejudiced against females that women managers would not succeed on expatriate assignments (Adler, 1994a). However Adler (1994b) found that respondents reported numerous benefits of being female. Most frequently, they described the advantage of being highly visible. Both foreign and local clients were curious about them, wanted to meet them, and remembered them after the first encounter (Adler, 1994a). Women believed foreigners view them firstly as representatives of a company, second as a citizen from where they originate, and lastly as women (Caligiuri, Joshi \& Lazarova, 1999; Stroh, Varma \& Valy-Durbin, 2000). Importantly, more recent research by Sinagil and Ones (2003), in which they surveyed expatriates currently working in Turkey, addressed the question of whether female expatriates can be successful in a cultural environment that may be perceived to be unfriendly to females by Western standards? They concluded that men and women expatriates on average were rated quite similarly in terms of their job performance, and that employing more women in the international workforce would enhance the quality of workforce diversity, build more inclusive contexts in expatriate assignments, albeit without decreasing job performance. It should be noted, thought, that again here the research 
examined primarily Western expatriates, and foreigner perceptions of Arab Islamic Middle Eastern women may be quite different.

\section{Corporate resistance}

Adler (1984a, 1984b) further suggested that a majority of disadvantages experienced by female expatriates involved a lack of organisational support (Adler, 1984a, 1984b). Corporate resistance has been viewed as arising from two sources: male colleagues' perceptions of, and an unsupportive corporate attitude towards female expatriates. Research proved that men only believed the women are qualified for career development in domestic positions, but not internationally (Adler, 1987; Harris, 1995). It has been argued that when the more powerful positions in organisations are filled almost exclusively by men (Selmer \& Leung, 2002: 350). It has also been argued that when companies select women for expatriation, it is often due to all potential male candidates having already turned down the assignment. Continually, companies prefer to offer women temporary or fly in/fly out assignments (Adler, 1994a;). Others report that closed, informal systems for expatriate selection are predominantly in place, severely restricting the pool of potential candidates (Harris \& Brewster, 1999; Harris, 2001; Linehan, Scullion \& Walsh, 2001). An additional study by Selmer and Leung (2002) found that career development activities and mentoring arrangements were also less available to female expatriates. Further research has examined the 'glass ceiling effect' which presents barriers to international selection. Some researchers also indicate a 'glass border', where companies hold assumptions about women as managers and their availability, suitability and preferences for international assignments (Linehan \& Walsh, 1999).

Another organisational issue related to the scarcity of females on international assignments is the international recruitment and selection processes for expatriate positions. Harris and Brewster (1999) conclude that the 'coffee machine system', is a common form of placing prospective expatriates on assignments. This happens when colleagues partake in 
closed/informal discussions around the coffee machine, which frequently leads to people being offered international assignments or recommendations of other colleagues capable of filling the position - thus connections are an important aspect of opportunities.

Research has suggested that women may experience less perceived organisational support when on expatriate assignment, because in many instances their workplace is predominantly male (Hutchings, French \& Hatcher, 2008). Research has further shown that managers receive increasing levels of support as they progress in the hierarchy (Johlke, Stamper \& Shoemaker, 2002). At lower levels of management, men are predicted to perceive more support compared to females (Adler, 1984a; Harris, 2001; Lineham, 2000). It has also been suggested that there are not enough women in senior international management positions to act as mentors (Linehan et al., 2001). These sorts of cultural practices are unlikely to be found in multinational corporations in the Middle East, however, where work segregation is common place.

\section{Female managers' disinterest}

Another common reason suggested for the lack of expatriate women is female disinterest in pursing expatriate positions (Adler, 1984a; Sinangil \& Ones, 2001). Stroh et al., (2000) found, in general, women are interested in and are liable to accept expatriate assignments abroad as frequently as males. The only apparent significant difference was when children were involved, where women became more likely to decline (Stroh et al., 2000). It should be noted that a range of academic research as well as studies by consulting organisations and indeed the research of Adler (1984a) herself exploded as a myth the perception that women were disinterested in international work, and that women's reluctance to take international assignments for personal reasons was not because of a lack of interest per se but rather because of family and broader social/community obligations (see Stroh et al., 
2000) and the gendered nature of their domestic and international career development and opportunities (see Myers \& Pringle, 2005; Tharenou, 2008).

\section{Lack of support}

A fourth barrier that can be identified that limits women's international work opportunities is that of a lack of social network or family support. Recent research has also found that a dearth of social network support available to female expatriates is also a significant barrier (Linehan, 2000; Linehan, et. al., 2001). Also, it has been suggested that females commonly receive less career development and mentoring, and while levels of support increase as individuals progress in the hierarchy, at lower levels of management (where selection decisions might be made about international opportunities), men are predicted to perceive more support compared to females (Adler, 1984a; Harris, 2001; Linehan, 2000). It could also be expected that cultural and institutional perceptions of women's roles in family and society might also be a factor in determining their international work opportunities.

\section{Women, globalisation and management in the Middle East}

The increasing engagement of Middle Eastern nations in the global economy has provided opportunities for Arab Middle Eastern women in the political and business spheres (Moghadam, 2005). The following tables provide insight into gender and development in the Arab Middle Eastern nations explored in this research relative to leading OECD nations.

Insert table 1 about here

Insert table 2 about here 
Research into the role of women in management within the context of the Arab Middle East is a field which has yet to be fully developed (Budhwar \& Mellahi, 2006) and the paucity of scholarship on HRM in the Middle East is explained partially by the fact that the phenomena of HRM is relatively recent within the Middle East. Similarly as in international management and international business research, gender has tended to be ignored as a category of social analysis. Current gender research in the Arab Middle East largely focuses on political participation, women's family roles and health issues rather than providing detailed critiques of corporate leadership and management (see for example, Barlow et al., 2006; El-Azury, 2003; El-Ghannam, 2002; Seikaly, 1994).

Recent research by Metcalfe $(2007,2006)$ has made a distinguished contribution to the international management and HRM literature in its comprehensive exploration of the interrelations between gender, organisational management systems, and Islamic values in the Arab Middle Eastern work environment. Metcalfe (2006) investigates the barriers to Arab Middle Eastern women's career advancement, and identifies work-family conflict, lack of diversity or equality frameworks in organisations and limited organisational and training support as significant barriers which impede women's career mobility.

These findings suggest that the experiences of women professionals in the Middle East are comparable to those of female managers in the West in that barriers or obstacles to international work may be similar. What is distinct and has not been comprehensively explored in literature on women in international management, though, is the complexity of Arab Middle Eastern gender and management relations and the need to understand business culture without applying a facile generalisation of a Western typology of organisational gender relations to the Middle East context. Al-Hamadi, Budhwar and Shipton (2007) emphasise that interrelation of national culture and business culture is particularly significant within the context of the Middle East, where the influence of religion on political and economic organisation is particularly pronounced. The Islamic religion provides guidelines 
encompassing all aspects of public and private existence, and the political and economic spheres. Metcalfe $(2007,2006)$ furthers the research by Tayeb (1997) and Rice (1999) in investigating the influence of the Islamic ethical framework on gender and human relations in suggesting that lack of HR policies concerned with equal opportunity initiatives viewed through an Islamic lens, is reflective of the "equal but different" philosophy which founds the ethics of Islamic gender relations. Metcalfe (2006) highlights how an Islamic gender order premised on an equal but different philosophy creates gendered work hierarchies which prescribe men's jobs and women's jobs; supporting segregation in many work spaces. Metcalfe $(2007 ; 2006)$ suggests, however, that this segregation need not be always be viewed as discriminatory and as limiting businesswomen's opportunities for advancing their careers, but can encourage women's engagement in their own business development pursuits, and has led to an expansion in the development of professional women's associations in the Arab Middle East.

In a review of recent literature on women in the Middle East, Keddie (2002) cautions against generalised assumptions about Middle Eastern women's opportunities, or as she later stated, the need to avoid perceptions of most Arab Islamic nations as being monolithic autocracies in which women are primarily victims (2004). Keddie (2002: 567) suggests that “among the many points relevant to women's history that arise from such contemporary scholarly literature are: (1) the great variability by time, place, class, and ethnic group in women's positions; (2) the degree to which Islamic law regarding women is and is not observed in practice - for example, women rarely inherit land (and some other property) according to law, but may be (partially?) compensated in other ways by their natal families; (3) the degree to which courts' documents and conclusions may deviate from the real situation and that court decisions may not be carried out; (4) the huge under-estimation of women's work in official statistics and the real nature of women's agricultural and "family" labor; and (5) the importance of the attitude and biases of researchers, some of whom tend to make 
women's situations look relatively good, while others stress male dominance and widespread female oppression and suffering" (Keddie, 2002: 567). Hence, it is critical in assessing women's opportunities that we realise that while we can gauge a range of perceptions that women hold, that there is need to avoid generalisation in a region that reflects great diversity. Al-Lamky (2007) summarises earlier research suggesting that in the Arabian Gulf societies, recently described as "bastions of patriarchy and male chauvinism" (Abdy, 2005; cited in AlLamky, 2007), it is widely believed that women's place is primarily at home and if professionally inclined, their participation is expected to be in the areas of education, health (mainly nurses) and other support or clerical jobs primarily at the lower end of organisational hierarchies - with leadership positions typically reserved for men. Yet, she also suggests that at this critical historical juncture in Arab history, there is substantive international pressure to improve women's situation in the region which has been echoed through a number of insightful reports and initiatives within a range of Arab Middle Eastern countries that draw attention to the lagging role of Arab women and the need to harness their potential for socioeconomic and political development (Al-Lamky, 2007). Global feminist networks have long advocated women's role in the development process and this has been ratified in the United Nations Millennium Development Goals which call for the eradication of inequalities between women and men in the political and economic spheres (UNIFEM, 2004). Arab Middle East governments, though, in varying degrees have developed institutional frameworks to help empower women and in particular encourage women's work and entrepreneurship opportunities. It is clear that in order to advance and deepen our knowledge of the complexities of gender and international management and HRM in the Arab Middle East scholars need to be able to contextualise their research in the juxtaposition of development and tradition. 


\section{Middle Eastern women in international management}

The extant literature on women and HRM in the Arab Middle East context does not specifically explore the issue of women's opportunities in international management. The current research undertakes to address this gap in the literature, and builds on prior studies of barriers to women in international management from a largely Western and MNCs perspective, and women and work within the Middle East to specially explore perceived barriers and facilitators of international work opportunities for Arab Middle Eastern women in the private, public and international NGOs sectors.

\section{METHOD}

\section{Sample and procedure}

The data for this exploratory study came from a survey conducted from August-December 2007 of 97 middle- and senior-level female managers in Bahrain, Egypt, Jordan, the Kingdom of Saudi Arabia (KSA), Oman, Qatar, and the United Arab Emirates. While it is recognised that Israel is a politically and strategically significant country within the region (and does have a significant Muslim and Arab population), and there would be value in studying it as well as nations within the region that have large Christian populations, this research was designed to specifically explore perceptions of women living and working within Arab Islamic Middle Eastern nations in order to elucidate whether there are cultural and institutional factors that are barriers or facilitators of their international work opportunities. The seven Arab Middle Eastern nations included in the study were chosen because they represent the diversity of economic and political development within the region and include nations which are strongly Islamic fundamentalist (KSA) as well as much more liberal and internationlised (the UAE). As well as being representative, the chosen nations were also ones in which one of the authors had previously conducted research and consulting and hence had 
a large pool of contacts and business association networks through which the survey could be administered.

The questionnaire was developed in English, and was largely administered in English to middle- and senior-level Arab Middle Eastern female managers, who are conversant in English and many of whom also work in international organisations which have English as their working language. For some respondents (25 in total) the questionnaire was translated and back-translated into Arabic by a research assistant fluent in Arabic and English. Women from middle and senior levels of employment were targeted because of the likelihood of them being conversant in English (the international business language) and being highly educated both factors suggesting a greater propensity for them to be considered for international work assignments. The questionnaire was administered by email by Arab Middle Eastern business contacts which the second author had acquired during previous consulting and training programs held in the selected countries. Potential respondents were approached by the aforementioned contacts and asked to complete the questionnaire and to send their responses electronically to the second author. The use of snowballing/convenience sampling through use of existing contacts does suggest the potential for sampling bias on the part of the researchers. However, it is a strategy that was also used by an international team of researchers currently reporting best practice in IHRM (Von Glinow et al., 2002: 150) and is also an approach regularly employed in developing countries as a means of gaining potential access. In particular, the existence of personal contacts is essential to undertaking business and arguably to receiving usable response rates for surveys in the Arab world (for further discussion, see Hutchings \& Weir, 2006). .

All potential respondents were assured of the confidentiality in which the data would be treated and the voluntary nature of participation. It is acknowledged that conducting research cross-culturally in an unfamiliar environment is problematic and that employees in developing countries can be reticent to be critical of management or government/political 
regimes and have tendencies to give socially desirable responses to surveys (see Hutchings, 2004; Xie, Roy, \& Chen, 2006). We have attempted to avoid these potential problems by gaining respondents through established business association network contacts held by one of the authors which would address respondents concerns about confidentiality of information and how the findings would be utilised.

\section{Characteristics of the sample}

A summary of background information on the 97 respondents is shown in Table 3. As shown in Table 3, the women were employed across a range of industries and occupations, with many employed in public, educational, and non-government organisations as is consistent with general trends in women's work in the region. In her research on the UAE, Abdulla (2006) suggests that Middle Eastern women highlight the value of public-sector employment because of work conditions that protect indigenous workers from unfair dismissal, guarantee of employment in cases of long absences due to family illness and paid maternity leave - as well as a lack of network ties within the private sector (which some achieve through working in their own businesses). We suggest that these women are also likely to favour NGOs because they provide opportunity for educational advancement and exposure to international experience through developmental programs for women. Some of the women already had international work experience while others do not. Respondents with a mix of experience was important for the analysis as the research focuses not just on Middle Eastern women's perceptions of barriers to international work but also their disposition towards participating in international work. One of the women (an American citizen of Arab ethnicity, whom was working in the KSA) was working outside her country of origin - all the other women surveyed were currently working within their country of birth, although many had prior international work experience, both within the Middle East as well as Europe and North America. 
It is acknowledged that conducting research cross-culturally in an unfamiliar environment is problematic and that employees in developing countries can be reticent to be critical of management or government/political regimes and have a tendency to centrality in their responses to surveys (see Hutchings, 2004; Xie, Roy, \& Chen, 2006).

Insert table 3 about here

\section{Survey instrument}

The items used in this survey were adapted from surveys which had been validated by Stroh, Varma, and Valy-Durbin (2000) and Vance and Paik (2001) in relation to barriers and opportunities for women and international employment. Additional Arab Middle Eastern culturally-specific questions and sub-sets of questions were developed by the authors. The survey included both close-ended and open-ended questions. The attitudinal items were rated on Likert-type rating scales. The wording of the close-ended survey items are reported in Tables 5-8. The survey instrument focused on:

- questions about training, development and education received by respondents in their current organisation and what they believe would assist their international employment prospects;

- respondents' personal experiences with fairness in employment opportunities;

- perceptions of Arab Middle Eastern women managers' interest/disinterest in international work;

- perceptions of corporate resistance to women's international work; and

- perceptions of foreign prejudice to women's international employment opportunities. 


\section{RESULTS}

\section{Cultural and organisational barriers}

As shown in Figure 1, over half of the respondents (53.6\%) reported that stereotypical perceptions of women managers were a barrier to their international career opportunities. In addition, limited training and education opportunities, lack of female role models, the business culture of the home country, and family commitments related to child rearing were each reported by approximately $40 \%$ of the women.

Insert Figure 1 about here

\section{Training, professional development and organisational supports}

Table 4 shows that leadership and team building was the most commonly mentioned education and training need $(67.0 \%)$ by the women. Other education and training needs mentioned by over half of the respondents were interpersonal skills (56.7\%) and human resource management $(54.6 \%)$.

Just over half of the respondents $(51.5 \%)$ had attended business/industry seminars as part of their professional development. However, far fewer women had developed an individual career plan $(28.9 \%)$ or had been advised/supported by a mentor (34\%). About a half of the sample (49.5\%) had attended NGO training programs. With regard to organisational supports, just over a third of the respondents reported a lack of opportunities for part-time and flexible working (36.1\%), and about a third (32\%) cited lack of child care facilities.

Insert table 4 about here 


\section{Attitudes to foreigner prejudice and cultural adjustment}

Table 5 shows that just over a third of respondents (36.2\%) either agreed or strongly agreed that host country cultures disadvantage Arab Middle Eastern women. A similar proportion either agreed or strongly agreed that 'host country nationals both inside and outside the company are prejudiced against female Arab Middle Eastern expatriates.' About half of the respondents (49.5\%) reported that female Arab Middle Eastern executives generally have more difficulty than do their male counterparts in coping with the aggressive atmosphere of business in an international context.

\section{Insert table 5 about here}

\section{Attitudes to corporate resistance}

Table 6 shows that the majority of respondents $(59.0 \%)$ of respondents either agreed or strongly agreed that Arab Middle Eastern companies are hesitant to send women on international assignments, compared with $30.2 \%$ who reported that international companies are hesitant to send women on international assignments. Just over half of the respondents (51.6\%) either agreed or strongly agreed that Arab Middle Eastern women who have children are offered fewer international assignments than Arab Middle Eastern women who do not have children. A slightly lower proportion of respondents (44.8\%) either agreed or strongly agreed that Arab Middle Eastern women who have a husband are offered fewer international assignments than Arab Middle Eastern women who do not have a husband; however it is worth noting that $38.5 \%$ reported a neutral opinion on this matter. We found no statistically significant differences in attitudes to corporate resistance by any of the demographic and organisation variables.

Insert table 6 about here 


\section{Attitudes to international assignments}

In general, the women had positive attitudes to international assignments. Table 7 shows that the majority of respondents $(66.0 \%)$ either disagreed or strongly disagreed with the proposition that they are not personally interested in going on international assignments. Interestingly, nearly a quarter of respondents (23.4\%) stated they were not personally interested in going on international assignments, and 34.0\% either agreed or strongly agreed with the proposition that Arab Middle Eastern women in general are not interested in going on international assignments.

Attitudes to international assignments varied by age, marital status and presence of children. All of those respondents who were aged 18-24 years expressed an interest in going on international assignments, compared with just over half $(55.6 \%)$ of those aged 35 years and over, and $64.5 \%$ of those aged $25-34$. Those women who were single were more likely to express personal interest in going on international assignments $(81.0 \%)$, compared with those who were married (54.5\%). Similarly, those respondents with no dependent children were more likely to express personal interest in going on international assignments $(78.6 \%)$, compared with those with children (47.4\%).

Interestingly, there was little variation in attitudes to international assignments by perceptions of corporate resistance or host country prejudice. However, women who either disagreed or strongly disagreed that female Arab Middle Eastern executives have more difficulty than do their male counterparts in coping with the aggressive atmosphere of business in an international context were far more likely to $(82.6 \%)$ express interest in going on international assignments, compared with just over half (54.1\%) of those who did not feel such difficulties.

A large majority of respondents (71.9\%) either agreed or strongly agreed that Arab Middle Eastern women who have children accept fewer international assignments than women who do not have children. A much smaller majority (54.7\%) either agreed or strongly 
agreed that Arab Middle Eastern women in dual-career relationships accept fewer international assignments than women who are single or whose husbands do not work.

While the majority of women $(64.2 \%)$ either disagreed or strongly disagreed that female Arab Middle Eastern executives generally are not as qualified for extended foreign work assignments as are male executives, about a quarter (24.2\%) either agreed or strongly agreed with this proposition. However, the overwhelming majority $(\mathbf{7 9 . 0 \%})$ either disagreed or strongly disagreed that they are not as qualified for extended foreign work assignments as are their male colleagues.

Insert table 7 about here

In addition to the quantitative data presented above, we also asked survey participants to respond to several open-ended questions which asked them about instances in which they had been rated unfairly at work, instances where they believed they had been treated unfairly in respect to international experiences, and organisational, cultural or institutional issues which they believe affect international work opportunities for them or other Arab Middle Eastern women. These open-ended questions were thematically analysed and summarized below. Quotations from the women are reported below to illustrate the diversity of experiences of Arab Middle Eastern women.

Experiences where women felt they were not fairly treated (for example in recruitment, selection, training, promotion)

In respect to women referring to situations in which they believed they had not been treated fairly, the responses focused on two key areas - interpersonal connections and gendered aspects of work. Several respondents argued that while qualifications and status are important 
aspects of Arab Middle Eastern society and business, that personal connections override them in recruitment and selection choices as well as opportunities for promotion. One respondent argued that "the recruitment procedure and ....job title....doesn't give the true appreciation of the person, and its all depend on personal connections" (Jordan 35). Importantly such connections are not necessarily gender-related with women for prominent political and business families having better opportunities than men from poorer families. So, in some instances, class may be a more important consideration than gender affecting opportunities, although it should be noted that many women will suffer a double disadvantage on gender and class grounds.

Women's opportunities for selection, training and promotion were also viewed as being clearly related to their gender with many respondents suggesting that they did not have the same opportunities as men who had equal or lesser qualifications and work experience. One respondent argued that "women are passed over for promotion ....they are not seen as being able to support departments" (Bahrain 44), while another argued that "men are always seen as more superior and given more opportunities - as a woman I constantly feel the need to prove myself" (Jordan 68). One woman academic provide details of how her gender affected her opportunities to ascertain support from her university to undertake PHD studies. As she stated

\footnotetext{
"There are no equal career opportunities between male and female in recruitment, selection, training or promotion, because men are preferred to women. My experience where I felt I was not fairly treated is that I wanted to continue my personal and professional development, through pursuing my $\mathrm{PhD}$ degree. Another male colleague who is older than me... and less experienced in teaching and researching applied at the same time to obtain his $\mathrm{PhD}$. For him it took only two months to have the organisation's approval. For me it took more than three years to have the organisation's approval. They (refer to the head office who are men) tried to make it so difficult for me in order to stop me from thinking about my goal. They tried to persuade me that 'women's branch do not need someone with a $\mathrm{PhD}$; there is a shortage of staff; you need to change your subject area, you are in the late thirties....no scholarship for people who reach this age; there are waiting lists and you should wait; there are not many universities interested in your area of research; the budget does not allows us to send you to study abroad,
} 
you have achieved a lot you do not need to obtain a $\mathrm{PhD}$, and if you insist on studying better do it as part time so you can work and study'. My colleague, finished his $\mathrm{PhD}$ and now he is looking for another promotion. Why they did that to me is it because I am a woman and they don not want me to compete with them (men)...the good opportunities...only reserved for male" (KSA 6).

Further, women's opportunities were also seen as being affected by their marital and motherhood status (or potential to marry and bear children). One woman from Jordan reported that "I was supposed to be the second in charge in the bank two years ago, but when I gave birth to my baby someone else was promoted though he is less experienced and qualified" (Jordan 36), while another maintained that organisations "fears training the female.... after a couple of months/years she is well trained.....she may get married and have babies......then she may quit" (Jordan 70). Interestingly, even though many professional women in the Arab Middle East have full-time housekeepers and child carers, the importance of their standing as wife and mother and perception that this is their primary role in life, blurs the lines between public and private spheres and affects their employment opportunities.

\section{International experiences where women felt they were not fairly treated (for example in}

\section{recruitment, selection, training, promotion)}

In respect to international experiences of unfair treatment or lack of opportunities for international experience, the women surveyed responded that opportunities were affected by either perceptions which Middle Eastern organisations had about Arab Middle Eastern women's abilities or perceptions which they believed that organisations or individuals in foreign nations had about Arab Middle Eastern women. In respect to the former issue many respondents suggested that Arab Middle Eastern organisations or foreign organisations operating within the Arab Middle East would not provide opportunities for Arab Middle Eastern women to work internationally because they believed that either they would not be accepted as international managers or that they were viewed as not as capable as men as 
managers. As one respondent argued "there is an Arabic mentality that only males can work internationally" (Jordan 70).

Several respondents reported that they had applied for jobs in Western countries but had not been selected for the positions and argued that they believed they had not been selected because of the part of the world in which they lived. One woman argued that "foreign managers want foreigners not Middle Eastern women as managers" (UAE 17). Respondents also suggested they believed that the lack of opportunities provided to them by foreign organisations was because of a combination of cultural stereotyping as well as political tensions between their societies and the Western world. One respondent claimed that "I am faced with mistreatment as a woman - people in the US/Europe have stereotypes of Arab women" (Jordan 72). An American citizen (of Arab ethnicity) who was working in Saudi Arabia at the time the survey was conducted reported that she was discriminated against because she was a foreigner even though she shares a cultural and religious heritage with her co-workers. As she commented,

"Well, currently I work with an employer that treats ALL her employees like we are her drivers and maids. In this country having the nationality of being American or European or Saudi is an advantage to getting a higher salary.....in this case she is not taking it into consideration. Most foreign women like myself have residency on my father's ekama (permit) and so I do not have the benefits. If my ekama was on my employer then 'perhaps' she would consider giving benefits. Even though I work as many hours as other men and women that have benefits I am being robbed of these rights that I believe should be given to ALL full-time workers. Now that is not being treated fairly...being taken advantage of. Since the contract that I currently have is not an official contract I technically do not have rights to argue with my employer regarding my salary. I had been promised a raise after a three month probation period which we had agreed upon before hiring. After six months of work I went to my employer and asked for my evaluation regarding my work performance that would result in the increase of my salary. We had agreed on the increase but once again I was promised but unfortunately denied my raise. Where are my rights here?" (KSA 21). 
Other issues which women believe have affected their international work opportunities or opportunities of Arab Middle Eastern women managers generally

In response to this question some respondents highlighted what can assist their domestic or international employment opportunities while others referred to impediments to their domestic international employment opportunities. Impediments that were noted focused on women rarely even being considered when managerial decisions are being made, and in the case of some nations, such as Saudi Arabia, where women are not allowed to drive, logistic obstacles to employment and networking opportunities. One respondent argued that there are "general cultural perceptions of women's inadequacy for managerial roles" (Oman 13), while another suggested it is women's own belief in themselves that impacts on empowerment and advancement. As she proffered, "in the Middle East women mistakenly believe that they are weak, sensitive, and not able to handle sophisticated tasks. This common misconception is negatively influencing women in the workplace and is creating fewer opportunities for them" (Jordan 18).

\section{Arab Middle Eastern women in international development}

On the positive side several respondents identified the value of having opportunities to work in international organisations while in their home country enriches work experience and could be leveraged for future international employment opportunities. Where respondents believed that they had skills and knowledge that was highly valued by international organisations they were largely referring to work that they had undertaken for United Nations (UN) or International Labour Organisation (ILO) projects or for other non-government organisations. A large percentage of respondents asserted the value of qualifications with one woman arguing that "professional and academic degrees, diplomas and certificates, increase women's opportunities to work on the international level...and grow and move higher in the job ladder" (Jordan 11). Another respondent highlighted the importance of having other Arab 
Middle Eastern women in senior positions who serve as role models. As she argued, "the biggest issue I saw in my working experience was when our own organisations and companies bring in specialists who are women and believe in their abilities and treat them professionally" (Jordan 15). The most frequently cited issue for advancing women's opportunities was the general need for belief in, and support for, Arab Middle Eastern women in their roles in organisations - support which needs to come from family, organisations and government. One respondent suggested the "need for a husband's understanding and support, and support by management" (Jordan 75) while another maintained that,

"my family is supportive but not all families are supportive of women working generally or working internationally. The Sheikh needs to do more to encourage women's roles in families as more than just a mother......we are intelligent, have business skills and usually more qualifications than many men. Women can lead the international development process...if they receive support to do so" (Oman 16).

\section{DISCUSSION}

The findings of this exploratory study support earlier research, namely Adler's, which suggested women's international opportunities were affected by foreigner prejudice and corporate resistance. While some of our respondents maintained that their organisations were opposed to women working internationally, most suggested that the problem was not actually about organisations directly preventing women from working internationally but that there was lack of initiatives to assist their management development for international experience. Our research found that females' own disinterest in international employment is also identified (in contrast to this barrier being largely dismissed as a myth in the Western context), with older married women with dependants being much more likely to report a lack of interest in undertaking international work. Few women provided responses arguing that they believed there was lack of support in expatriate communities as had been previously suggested by Linehan (2000) as well as Hutchings, French and Hatcher (2008), but this could 
be because respondents had limited international experience or because the nature of their work tended to be in NGOs rather than MNCs and these people may have had a stronger support network than individuals working in the private sector. While not directly referring to it as such, respondents did support Harris and Brewster's (1998) assertion of there being a coffee machine selection process, with many respondents arguing that there is a gendered nature of international employment. There was also evidence of support for early research into Middle Eastern women in domestic work undertaken by Metcalfe (2006), Tayeb (1997) and Rice (1999) with respondents suggesting that their opportunities are affected by work/family conflict, lack of equal opportunity practices in Arab Middle Eastern nations, cultural and Islamic attitudes to sex roles as well as a concept of Arab Middle Eastern women being 'equal but different'.

The findings further suggest that the respondents believe that there is much to be gained by government policies which provide leadership and training programs for women as well as industry meetings and NGO training programs. Respondents argued that organisations provide very little in the way of equal employment opportunity workplace practice and called for the introduction of workplace crèches, and anti-sexual harassment and discrimination practices in a domestic context which would then provide a foundation for women to leverage international opportunities. In addition to a lack of supportive practices many women also commented that there are still organisational barriers to employment within Arab Middle Eastern nations (which then impacts on opportunities for international work), citing stereotypes of women managers, lack of a family-friendly work culture, and lack of strong female role models. In respect to the latter issues, the evidence suggests that Arab Middle Eastern women are calling for the equal employment opportunities that were enacted in most Western nations throughout the 1980s and 1990s and view this as fundamental to achieving equal opportunities from which international employment opportunities may then grow. 
While much of the findings are consistent with earlier research suggesting lack of corporate support and perceived (or real) foreigner prejudice, what is most interesting about our research is the impact of the local cultural environment in the Arab Middle East on women's domestic and international work opportunities. Significantly, a number of respondents pointed to the role of wasta (interpersonal connections) in affecting women's opportunities and argued that such connections can override gender in the workplace i.e. if women are from well-connected, prominent, wealthy families then they may have equal opportunities to their less well-connected male counterparts. And while there may be more male recruitment, training and promotion opportunities for males, women who come from wealthy families may actually be able to find international work experiences irrespective of women generally receiving less support in HR functional areas.

A key finding from our study is that international work experiences need to be more broadly defined to incorporate those activities outside of transnational corporations, namely all forms of international development and associated human rights and social justice roles. Importantly while Arab Middle Eastern women may suffer from foreigner prejudice based on cultural and religious stereotypes and may not be considered by private and MNC organisations for international work, they do benefit from training and job opportunities being provided by women's NGOs, women's professional organisations and governmental agencies responsible for women's issues which, they argued, tend to be less gender factionalised than MNCs. The internationalisation of discourses of equality, empowerment, autonomy, democratisation participation and human rights has been captured and extended by women's organisations globally. Global feminisms is responding to political-cultural movements, including forms of fundamentalism, thereby creating opportunities for women to participate and contribute to global and regional agendas of social development and change (Barlow et al., 2006). It is certainly a weakness that the current international management literature is dominated by concerns to evaluate the HR practices and institutional structures of MNCs and 
has ignored managerial systems in international agencies such as NGOs, the ILO, and United Nations subsidiaries. International organisations play a vital role in economic and social development and play a key role in nurturing learning and knowledge transfer, within/across organisations and cultures as our study exemplifies. International agencies and NGOs play a pivotal development role in educating women about employment rights, opportunities and professional skills. In addition international agencies such as the UN and ILO have also provided the foundations upon which organisation, training and equality principles can be benchmarked as illustrated inter alia by regulations and labour standards.

While respondents suggested that there is a need for government policies and organisational support for women's opportunities, they maintain that the greatest change required is social change and the provision of support from husbands and families to allow women to manage their work/family responsibilities and to provide them with the capacity to undertake international work. This aspect of our research extends other IHRM literature on expatriate management in proffering the need for changing thinking about the gendered nature of economic earning and dominant partners on international assignments. Our findings also add to extant research on women in international assignments in arguing that in addition to foreigner prejudice, corporate resistance and females' own disinterest in international work is the need for national social change (and family and network support) to assist women's perceived value as potential international managers.

\section{CONCLUSIONS}

\section{Theoretical implications}

There are three key theoretical contributions of this exploratory research. First, the research broadens existing literature on women in international management from a focus largely on Western expatriate females to an examination of Arab Middle Eastern women's perceptions of barriers and facilitators of international work for them and their peers. Second, this 
research is significant in that it extends our understanding of what is international work. In current theoretical argument it is assumed that international work experience is gleaned from international assignments in MNCs. Underpinning this is an assumption of Western-based forms of capital organisation and structures. Overwhelmingly, the women in our study worked in international assignments in non-government organisations and international development agencies as well as working intra-regionally. The results, therefore, lend support to earlier research which explored whether there is foreigner prejudice but suggests that stereotypical judgements that might potentially be made about Arab Middle Eastern women were perceived as occurring primarily in MNCs whereas international NGOs and agencies were perceived as providing a more supportive and developmental environment. Our research suggests that critical debate of work and organisation needs to move beyond dominant understandings of private and public sector employment. Third, this research builds upon Adler's categorisation of barriers to women's international work (foreigner prejudice, corporate resistance, and women's own lack of interest) and more recent research on the role of family and other support mechanisms to also consider impediments to women's international work opportunities based on specific national cultural and institutional barriers. It is important to recognise that this research questions the universalism of Western women's international management experience. This is borne out by the fact that economic growth and development is occurring in developing and transition economies and their experience of internationalisation is markedly different. It is acknowledged, however, that the data collected is based on a relatively small sample size and that an examination of attitudes and perceptions of women in six Arab Middle Eastern nations may not be generalisable to other Middle Eastern countries or other Islamic or developing nations. Nonetheless, the research does highlight the need to explore national factors as barriers to women's international work prospects. 


\section{Limitations and Issues for Future Research}

Despite the significant contribution this research makes in developing earlier research on women in international management and exploring a hitherto under-researched area, namely issues around work and employment for Arab Middle Eastern women, there are three key limitations of this research which highlight the need for further research. First, we surveyed women currently working within the selected seven Arab Middle Eastern nations. With the exception of one individual who was an American citizen of Arab ethnicity, all of the other respondents were working within their own home country or a neighbouring Middle Eastern country. So, the findings of this survey are limited to the experiences of Arab Middle Eastern women working within other Arab Middle Eastern nations. There is a need for future research to survey Arab Middle Eastern women who are currently on an international assignment, or have previously held an assignment, outside the Middle East - this would allow for testing of the foreigner prejudice barrier identified by Adler's research. Second, we only surveyed women about their experiences working domestically and internationally in the Arab Middle East and their perceptions of barriers to Arab Middle Eastern women's domestic and international opportunities. It would also be beneficial for future research to survey men in the Middle East and compare their perceptions of Middle Eastern women's opportunities and barriers to recruitment, training and promotion, with the responses provided by women. Third the focus of our research mirrored and built upon Adler's research into barriers to women's opportunities. There is need for future research to also explore positive experiences with work and employment internationally in asking women to report situations and experiences in which their skills and knowledge are valued by organisations, government and society and what can be done to maximise their international employment opportunities. Specifically, this should also incorporate assessment of women's work in international organisations. More generally IHRM literature needs to consider HR practices in international agencies. Fourth, our sample size was not sufficient to specifically explore whether there were differences in 
perceptions in differing countries - this could potentially be expected given the vast range of political, socio-economic, and developmental experiences of countries in the region. Moreover, future research might be extended beyond Islamic-dominated countries to also consider countries with differing religious bases, such as Israel, in which most people are practicing Judaism, or Lebanon, in which a large percentage of the population are Christians, and whether these factors impact on perceptions of international opportunities.

\section{Managerial/HRM implications}

This research identified the need for organisations and Arab Middle Eastern governments to provide initiatives to assist Arab Middle Eastern women's work and employment opportunities domestically and internationally within and outside the Arab Middle East. Within organisations in the Arab Middle East there is need for senior and HR managers to implement equal employment opportunity policies which encompass work-life balance programs such as provision of child care or child care subsidies and flexible or teleworking work hours. Organisations also need to provide career development plans for women which recognise the importance placed on child raring and family responsibilities within the Arab nations. Further, organisations need to provide mentors and role models for women and showcase the achievements of successful women within their organisations to provide impetus to other women to aim for senior positions, as well as communicating clearly all policies and training staff in equal employment opportunity practices.

To assist Arab Middle Eastern women to maximise their potential for international employment, organisations in the Arab Middle East could provide secondments and shortterm international assignment postings or cultural exchanges to other counties as well as ensuring that women have equal access to training and cross-cultural training. Moreover, as has begun to occur in the Western world, there is need for cognisance of dual career issues 
and assistance in providing jobs for male trailing spouses where women are posted internationally.

In addition to initiatives that can be taken by organisations to assist women's international employment prospects, though, there is a necessity for overall national culture and value change in Arab Middle Eastern nations; change which can be led by government plans to promote equal opportunities for women through enactment of Anti-Sexual Harassment and Anti-Discrimination legislation, Women's development plans, and Equal Employment Opportunity campaigns. 


\section{REFERENCES}

Abdalla, I. A. (1996) 'Attitudes Towards Women in the Arabian Gulf Region', Women in Management Review, 11(1): 29-39.

Abdulla, F. (2006)' Education and Employment among Women in the UAE', International Higher Education: Economic Issues, Issue 45.Boston: Boston College Center for International Higher Education, p.9.

Adler, N. (1984a) 'Women in International Management: Where are They?', California Management Review, 6: 79-89.

Adler, N. (1984b) 'Expecting International Success: Female Managers Overseas', Columbia Journal of World Business, 19: 77-83.

Adler, N. (1984c) 'Women Do Not Want International Careers: And Other Myths About International Management', Organisational Dynamics, 13(2): 66-79.

Adler, N. (1987) 'Pacific Basin Managers: A Gaijin, Not a Woman', Human Resource Management, 26: 169-91.

Adler, N. (1994a) 'Competitive Frontiers: Women Managing Across Borders', Journal of Management Development, 13(2): 24-41.

Adler, N. (1994b) 'Competitive Frontiers: Women Managing Across Borders'. In Adler, N. and Izraeli, D. (eds.) Competitive Frontiers: Women Managers in a Global Economy. Oxford: Blackwell, pp. 23-42.

Al-Hamadi, A. B., Budhwar, P. S. and Shipton, H. (2007) 'Management of Human Resources in Oman', The International Journal of Human Resource Management, 18(1): 100-113.

Al_Lamky, A. (2007) 'Feminizing leadership in Arab societies: the perspectives of Omani female leaders', Women in Management Review, 22(1): 49-67.

Altman, Y. and Shortland, S. (2001) 'Women, aliens and international assignments', Women in Management Review, 16(3): 141-146.

Barlow, R. and Akbarzadeh, S., (2006) 'Womens Rights in the Muslim World?' Reform or Reconstruction', Third World Quarterly, 27(8): 1481-1494.

Budhwar, P.S. and Mellahi, K. (2006) Managing Human Resources in the Middle East. Abingdon: Routledge.

Caligiuri, P. and Cascio, W. (1998) 'Can We Send Her There? Maximising the Success of Western Women on Global Assignments', Journal of World Business, 33(4): 394-417.

Caligiuri, P., Joshi, A. and Lazarova, M. (1999) 'Factors Influencing the Adjustment of Women on Global Assignments', The Journal of Human Resource Management, 10(2): 16379 . 
Cordano, M., Scherer, R.F., and Owen, C.L. (2002) 'Attitudes towards women as managers: sex versus culture', Women in Management Review, 17(2): 51-60.

El-Azhary, A. (2003). Women of Jordan, Islam Labor and the Law, New York: Syracuse University Press.

El-Ghannam, A. (2002), 'Analytical Study of Women's Participation in Economic Activities in Arab Societies', Equal Opportunities International, 21: 1-18.

Harris, H. (1995) 'Organizational Influences on Women's Career Opportunities in International Management', Women in Management Review, 10(3): 26-31.

Harris, H. (2001) 'Researching Discrimination in Selection for International Management Assignments: The Role of Repertory Grid Technique', Women in Management Review, 16(3): $118-125$.

Harris, H. (2004) 'Global Careers: Work-life Issues and the Adjustment of Women International Managers', Journal of Management Development, 23(9): 818-32.

Harris, H. and Brewster, C. (1999) 'The Coffee Machine System: How International Selection Really Works', International Journal of Human Resource Management, 10(3): 459-76.

Hearn, J. Metcalfe, B., and Piekkari, R. (2006). 'Gender and International Human Resource Management'. In Bjorkman, I, and Stahl, G. (Eds.) Handbook of International Human Resource Management, London: Edward Elgar, pp.502-522.

Heneman, H., Judge, T. and Heneman, R. (1999) Staffing Organisations. Middleton: Irwin McGraw-Hill.

Hutchings, K. (2004) Behind the Bamboo Curtain: Problems and Pitfalls in Doing Research with Expatriates in China, In Fieldwork in Transforming Societies: Understanding Methodology from Experience, Ed. S. Michailova \& E. Clark, London: Palgrave, pp. 136-156.

Hutchings, K., French, E. and Hatcher, T. (2008) 'Lament of the ignored expatiate: An examination of organisational and social network support for female expatriates in China', Equal Opportunities International, 27(4): 372-91.

Hutchings, K. and Weir, D. (2006) 'Understanding Networking in China and the Arab World: Lessons for International Managers', Journal of European Industrial Training, 30(4): 272-90.

Johlke, M., Stamper, C. and Shoemaker, M. (2002) 'Antecedents to Boundary-Spanner Perceived Organizational Support', Journal of Managerial Psychology, 17(2): 116-28.

Keddie, N.R. (2002) 'Women in the limelight: Some recent books on Middle Eastern women's history', International. Journal of Middle East Studies, 34: 553-573.

Keddie, N.R. (2004) 'A Woman's Place: Democratization in the Middle East', Current History, 103(669): 669-677.

Linehan, M. (2000) Senior Female International Managers: Why So Few? Vermont: Ashgate Publishing. 
Linehan, M., Scullion, H. and Walsh, J. (2001) 'Barriers to Women's Participation in International Management', European Business Review, 13(1): 10-18.

Metcalfe, B.D. (2006) 'Exploring Cultural Dimensions of Gender and Management in the Middle East', Thunderbird International Business Review, 48(1): 93-107.

Metcalfe, B. D. (2007) 'Gender and Human Resource Management in the Middle East', The International Journal of Human Resource Management, 18(1): 54-74.

Moghadam, V. (2005). 'Women's Economic Participation in the Middle East', Journal of Middle East Women's Studies, 1(1): 110-146.

Mostafa, M. (2003) 'Attitudes Towards Women Who Work in Egypt', Women in Management Review, 18: 252-66.

Mostafa, M. (2005) 'Attitudes Towards Women Managers in the United Arab Emirates: The Effects of Patriarchy, Age, and Sex Differences,' Journal of Managerial Psychology, 20(5/6): $522-40$.

Myers, B. and Pringle, J.K. (2005) 'Self-initiated foreign experience as accelerated development: Influences of gender', Journal of World Business, 40(4): 421-431.

Nishii, L.H. and Ozbilgin, M. (2007). 'Global Diversity Management: A Conceptual Framework’, International Journal of HRM, 18(11): 1993-1894.

Rice, G. (1999) Islamic Ethics and the Implications for Business, Journal of Business Ethics, 18(4): 345-358.

Seikaly, M. (1994) 'Women and Social Change in Bahrain', International Journal of Middle East Studies, 26(3): 415-26.

Selmer, J. and Leung, A. (2002) 'Career Management Issues of Female Business Expatriates', Career Development International, 7(6): 348-58.

Selmer, J. and Leung, A. (2003) 'International Adjustment of Female Vs Male Business Expatriates', The International Journal of Human Resource Management, 14(7): 1117-31.

Sinangil, H. and Ones, D. (2001) 'Expatriate Management'. In Anderson, N., Ones, D., Sinangil, H. and Viswesveran, C. (eds.) Handbook of Industrial, Work \& Organisational Psychology. London: Sage.

Sinangil, H. and Ones, D. (2003) 'Gender Differences in Expatriate Job Performance', Applied Psychology, 52(3):461-475,.

Stroh, L., Varma, A. and Valy-Durbin, S. (2000) 'Why are Women Left at Home: Are They Unwilling to go on International Assignments?', Journal of World Business, 35(3): 241-255.

Taylor, S., Beechler, S. and Napier, N. (1996) 'Toward an Integrative Model of Strategic International Human Resource Management', Academy of Management Review, 21(4): 95985 . 
Tayeb, M. (1997) 'Islamic Revival in Asia and Human Resource Management', Employee Relations, 19(4): 352.

Tharenou, P. (2008) 'Disruptive decisions to leave home: Gender and family differences in expatriation choices', Organizational Behavior and Human Decision Processes, 105(2): 183200.

United Nations Development Programme (UNDP) (2005) The Arab Human Development Report: Empowerment of Arab Women, New York: UNDP.

United Nations Development Programme (UNDP) (2006) Human Development Report: Beyond Scarcity: Power, Poverty and the Global Water Crisis. New York: UNDP.

UNIFEM. (2004). Progress of Arab Women, New York, UNIFEM.

Van der Boon, M. (2003) 'Women in International Management: An International Perspective on Women's Ways of Leadership', Women in Management Review, 18(3/4): 132-46.

Vance, C. M. and Paik, Y. (2001) 'Where Do American Women Face their Biggest Obstacle to Expatriate Career Success? Back in Their Own Backyard', Cross Cultural Management, 8(3/4): 98-116.

Von Glinow, M.A., Drost. E.A. and Teagarden, M.B. (2002) 'Converging on IHRM Best Practices: Lessons Learned from a Globally Distributed Consortium on Theory and Practice', Asia Pacific Journal of Human Resources, 40(1): 146-66.

Xie, J.L., Roy, J.P., \& Chen, Z.G. (2006) 'Cultural and individual differences in self-rating behavior: An extension and refinement of the cultural relativity hypothesis, Journal of Organizational Behavior, 27:341-364. 


\section{Table 1: HDI, GDI and GEM Ranking}

\begin{tabular}{|llll|}
\hline Nation & HDI & GDI & GEM \\
\hline Bahrain & 39 & 38 &.. \\
Egypt & 111 &. & 73 \\
Jordan & 86 & 69 &.. \\
KSA & 76 & 72 & 74 \\
Oman & 56 & 57 &. \\
UAE & 49 & 49 & 70 \\
\hline Australia & 3 & 3 & 8 \\
UK & 18 & 16 & 16 \\
USA & 8 & 8 & 12 \\
\hline
\end{tabular}

1. The Human Development Index (HDI) is a composite index that measures the average achievement in a country on three basic dimensions: long, healthy life measured by life expectancy at birth; knowledge measured by adult literacy rate and combined gross enrolment ratio for primary, secondary and tertiary schooling; and a standard of living as measured by GDP per capita in purchasing power parity in USD dollars.

2. The Gender Development Index (GDI) is a measure of human development that adjusts the HDI to penalise for disparities between women and men in the three dimensions of the HDI.

3. The Gender Empowerment Measure (GEM) was intended to measure women's and men's abilities to participate actively in economic and political life and their command over economic resources. It measures three dimensions of agency: political participation and decision making power; economic participation and decision making power; and command over economic resources.

Source: Adapted from UNDP 2006 Human Development Report 
Table 2: Gender and Employment Measures

\begin{tabular}{|c|c|c|c|c|c|c|}
\hline Nation & $\frac{\text { Incom }}{\underline{\text { Do }}}$ & $\frac{\text { in US }}{\operatorname{lars}}$ & $\frac{\frac{\text { Economic }}{\text { Activity Rate }}}{\frac{\text { \% (15 and }}{\text { over) }}}$ & $\frac{\frac{\text { Women in }}{\text { Government }}}{\frac{\text { Ministerial }}{\underline{\text { Level \% }}}}$ & $\frac{\text { Seats in Lower }}{\underline{\text { House \% }}}$ & $\frac{\text { Seats in Upper }}{\text { House \% }}$ \\
\hline Bahrain & 29,107 & 9.654 & 29.2 & $8.79(2005)$ & $0(2006)$ & $15(2006)$ \\
\hline Egypt & 6,817 & $\overline{1,588}$ & $\overline{20.1}$ & $5.9(2005)$ & $2.0(2006)$ & $6.8(2006)$ \\
\hline Jordan & $\overline{7,038}$ & 2,143 & $\overline{27.0}$ & $10.7(2005)$ & $5.5(2006)$ & $12.7(2006)$ \\
\hline KSA & 22,617 & 3,486 & $17.3(2004)$ & 0 & 0 & 0 \\
\hline Oman & 23,223 & 4,273 & 21.9 & 10 & $2.4(\overline{2006)}$ & $15.5 \overline{(2006)}$ \\
\hline UAE & $\overline{31,788}$ & $\overline{7,630}$ & $\overline{37.4}$ & $\overline{5.6}$ & $\underline{0}$ & $\underline{0}$ \\
\hline Australia & $\overline{35,832}$ & 24,277 & $\overline{56.1}$ & $20.0(2005)$ & $24.7(2006)$ & $35.5(2006)$ \\
\hline UK & $\overline{37,506}$ & 24,448 & $\overline{55.0}$ & $28.6(2006)$ & $19.6(2006)$ & $17.5(2006)$ \\
\hline USA & 4,075 & $\overline{30,581}$ & $\overline{59.6}$ & $14.3(2005)$ & $15.2(2006)$ & $14.0(2006)$ \\
\hline
\end{tabular}

1. No wage data is available. For the purposes of calculating the estimated female and male earned income a value of 0.75 was used for the ratio of the female agricultural/rural wage to the make agricultural/rural wage.

2. Note that women are not allowed to vote in KSA or UAE. Also note that UAE has not signed the UN Convention on the Elimination of All Forms of Discrimination Against Women.

3. Women are appointed by the ruling government to ministerial seats in Bahrain and UAE.

Source: Adapted from_UNDP 2006 Human Development Report 
Age

Nationality

Bahraini

Marital status

Single

45.3

Married

Divorced/widowed

Dependents

Respondents without dependents

Highest educational qualification

Postgraduate (Doctorate/ Master's degree/MBA/ )

Bachelor's degree

Other qualification

Occupation

Director/owner

12.5

Professional/senior management

Middle management

Supervisor/team leader

1-49 employees

50-249 employees

250-499 employees

14.9

500 and over employees

34.0

Industry

Banking, insurance and finance

Education

19.0

Health

Manufacturing

Public administration

Petrochemicals

Non-government organisation

17.9

International agency

18.9

Business owner 


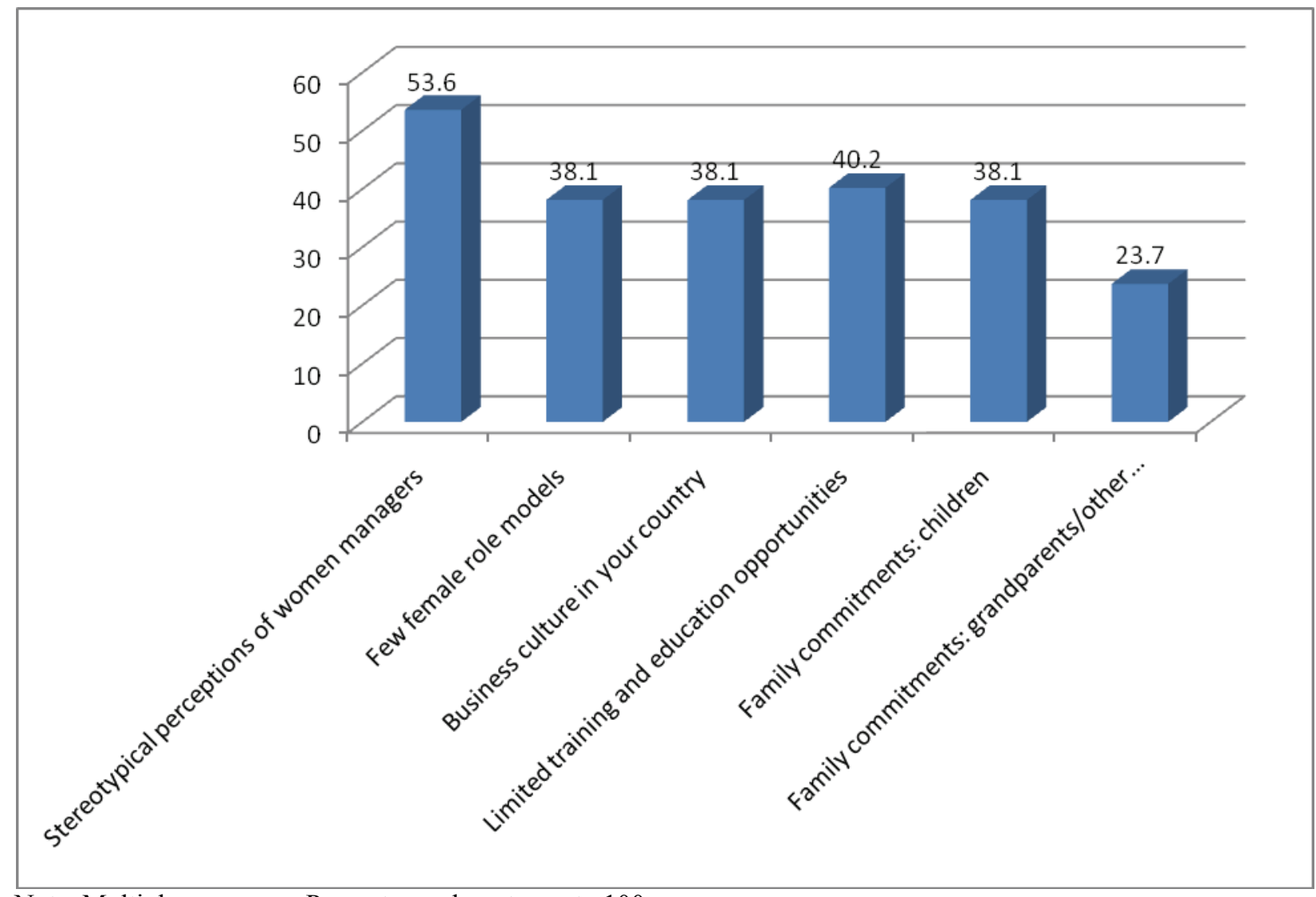

Note. Multiple responses. Percentages do not sum to 100.

Figure 1: Perceptions of organisational and cultural barriers (\%) 
$\underline{\text { Table 4: }}$ Training, professional development and organisational supports $\underline{(\%)}$

\begin{tabular}{|c|c|c|}
\hline \multirow[t]{8}{*}{ Education/training needs(a) } & Business and administration & 42.3 \\
\hline & Leadership and team building & 67.0 \\
\hline & Interpersonal skills & 56.7 \\
\hline & Performance management & 42.3 \\
\hline & Human resource management & 54.6 \\
\hline & Quality management & 29.9 \\
\hline & Technical/computing & 40.2 \\
\hline & Intercultural management skills & 41.2 \\
\hline \multirow[t]{8}{*}{ Professional development(a) } & Acted as a mentor & 39.2 \\
\hline & Advised/supported by a mentor & 34.0 \\
\hline & Developed an individual career plan & 28.9 \\
\hline & Attended business/industry seminars & 51.5 \\
\hline & Attended women's professional organisations & 33.0 \\
\hline & Attended government women's development and training & 25.8 \\
\hline & Attended NGO training programs & 49.5 \\
\hline & Attended UN/ILO seminars & 20.6 \\
\hline \multirow[t]{3}{*}{ Organisational supports } & Crèche/child care & 32.0 \\
\hline & Opportunities for part-time and flexible working & 36.1 \\
\hline & Opportunities for teleworking & 7.2 \\
\hline & & \\
\hline & & \\
\hline
\end{tabular}

Note. (a) multiple response questions. Percentages do not sum to 100 with categories. 
Table 5: Attitudes to foreigner prejudice and cultural adjustment (\%)

\begin{tabular}{|c|c|c|c|c|c|}
\hline & $\begin{array}{l}\text { Strongly } \\
\text { disagree }\end{array}$ & Disagree & Neutral & Agree & $\begin{array}{l}\text { Strongly } \\
\text { agree }\end{array}$ \\
\hline $\begin{array}{l}\text { Host country cultures disadvantage Middle Eastern } \\
\text { women. }\end{array}$ & 11.7 & 14.9 & 37.2 & 18.1 & 18.1 \\
\hline $\begin{array}{l}\text { In general, host country nationals both inside and } \\
\text { outside the company are prejudiced against female } \\
\text { Middle Eastern expatriates. }\end{array}$ & 8.5 & 14.9 & 39.4 & 25.5 & 11.7 \\
\hline $\begin{array}{l}\text { Because of their more sensitive natures, female } \\
\text { Middle Eastern executives generally have more } \\
\text { difficulty than do their male counterparts in coping } \\
\text { with the aggressive atmosphere of business in an } \\
\text { international context. }\end{array}$ & 10.5 & 18.9 & 21.1 & 26.3 & 23.2 \\
\hline
\end{tabular}


Table 6: Attitudes to corporate resistance (\%)

\begin{tabular}{|c|c|c|c|c|c|}
\hline & $\begin{array}{l}\text { Strongly } \\
\text { disagree }\end{array}$ & Disagree & Neutral & Agree & $\begin{array}{c}\text { Strongly } \\
\text { agree }\end{array}$ \\
\hline $\begin{array}{l}\text { Middle Eastern companies are hesitant to send women on } \\
\text { international assignments. }\end{array}$ & 5.2 & 16.7 & 18.8 & 26.0 & 33.0 \\
\hline $\begin{array}{l}\text { International companies are hesitant to send women on } \\
\text { international assignments. }\end{array}$ & 14.6 & 31.2 & 24.0 & 16.7 & 13.5 \\
\hline $\begin{array}{l}\text { Middle Eastern women who have children are offered fewer } \\
\text { international assignments than Middle Eastern women who do not } \\
\text { have children. }\end{array}$ & 6.3 & 10.5 & 31.6 & 31.6 & 20.0 \\
\hline $\begin{array}{l}\text { Middle Eastern women who have a husband are offered fewer } \\
\text { international assignments than Middle Eastern women who do not } \\
\text { have a husband. }\end{array}$ & 5.2 & 11.5 & 38.5 & 26.0 & 18.8 \\
\hline
\end{tabular}


Table 7: Attitudes to international assignments (\%)

\begin{tabular}{|c|c|c|c|c|c|}
\hline & $\begin{array}{l}\text { Strongly } \\
\text { disagree }\end{array}$ & Disagree & Neutral & Agree & $\begin{array}{l}\text { Strongly } \\
\text { agree }\end{array}$ \\
\hline $\begin{array}{l}\text { In general, Middle Eastern women are not interested in going on } \\
\text { international assignments. }\end{array}$ & 11.3 & 25.8 & 28.9 & 12.4 & 21.6 \\
\hline I am not interested in going on international assignments. & 41.5 & 24.5 & 10.6 & 8.5 & 14.9 \\
\hline $\begin{array}{l}\text { Middle Eastern women in dual-career relationships accept fewer } \\
\text { international assignments than women who are single or whose } \\
\text { husbands do not work. }\end{array}$ & 3.2 & 15.8 & 26.3 & 34.7 & 20.0 \\
\hline $\begin{array}{l}\text { Middle Eastern women who have children accept fewer } \\
\text { international assignments than women who do not have children. }\end{array}$ & 9.4 & 6.2 & 12.5 & 36.5 & 35.4 \\
\hline $\begin{array}{l}\text { Female Middle Eastern executives generally are not as qualified } \\
\text { for extended foreign work assignments as are male executives. }\end{array}$ & 44.2 & 20.0 & 11.6 & 13.7 & 10.5 \\
\hline $\begin{array}{l}\text { I am not as qualified for extended foreign work assignments as } \\
\text { are my male colleagues. }\end{array}$ & 57.8 & 21.1 & 6.3 & 7.4 & 7.4 \\
\hline
\end{tabular}

